\section{Hypertension in Climacteric: Prevalence and Intensity of Symptoms}

\title{
Abstract
}

Introduction: Menopause is a phase in the female life cycle marked by the end of menstruation, which some women experience in a healthy way, while others experience symptoms that vary in their diversity and intensity. One pathology that is evident in climacteric is systemic arterial hypertension (SAH), mainly during the postmenopausal phase. SAH is characterized by high blood pressure levels, which can trigger diseases.

Objective: To determine the prevalence of SAH and the intensity of symptoms in menopausal women in a city of Northeastern Brazil.

Method: This is a quantitative, cross-sectional study. Using a sample of 396 women between 40 and 60 years old, the study was performed at all family health units in the municipality of Cajazeiras-PB. The data were collected through structured interviews and were analyzed using the SPSS Statistics software package.

Results: The average age of the women interviewed was $50( \pm 5.801)$. They had, on average, $7( \pm 4.733)$ years of study and per capita incomes of $0.5( \pm 0.6958)$ times the minimum wage. A total of $69.9 \%$ ( $n=277)$ had a fixed companion, and $51.8 \%(n=205)$ were white. The prevalence of SAH was $35.1 \%$. SAH was associated with age [OR: 2.164 (95\% Cl 1.417-3.306)], activity in the home [OR: $1.686(95 \% \mathrm{Cl}$ 1.103-2.576)], overweight/obesity [OR: 2.748 (95\% Cl 1.738-4.343)], menopause/post-menopause [OR: $2.180(95 \% \mathrm{Cl} 1.432-3.321)]$ and heightened symptomatology [OR: 3.143 (95\% Cl 1.608-6.146)]. The menopausal symptoms that were more prevalent in hypertensive subjects were arthralgia (84.9\%), nervousness (84.2\%) and fatigue (81.3\%).

Jéssika Lacerda de Souza ${ }^{1}$ Maria do Carmo Andrade Duarte de Farias ${ }^{2}$, Kennia Sibelly Marques de Abrantes 3,5 , Arieli Rodrigues Nóbrega Videres ${ }^{3}$, Renan Alves Silva ${ }^{4}$, Betânia Maria Pereira dos Santos ${ }^{3}$, Marina Mendes Luiz ${ }^{3}$, Eliane de Sousa Leite ${ }^{3}$, Kévia Katiúcia Santos Bezerra², Anne Milane Formiga Bezerra ${ }^{1}$, Geofabio Sucupira Casimiro², Veruscka Pedroza Barreto², Anúbes Pereira de Castro ${ }^{3}$, Luiz Carlos de Abreu $^{5}$, Maria Soraya Pereira Franco Adriano ${ }^{6}$

1 Nurse in the Mobile Emergency Service, MSU, Sousa, PB, Brazil.

2 Academic Unit of Life Sciences, Teacher training center, Federal University of Campina Grande. Cajazeiras, Paraíba, Brazil.

3 Academic Unit of Nursing, Teacher training center, Federal University of Campina Grande. Cajazeiras, Paraíba, Brazil.

4 Graduate-degree in Nursing, Federal University of Ceará. Fortaleza, Ceará, Brazil.

5 Scientific Writing Laboratory, Faculty of Medicine of ABC, Santo Andre, SP, Brazil.

6 Federal University of Paraíba. João Pessoa, Paraíba, Brazil.

\section{Contact information:}

Maria do Carmo Andrade Duarte de Farias. Academic Unit of Life Sciences, Teacher training center, Federal University of Campina Grande

झ carmo.andrade@ufcg.edu.br
Keywords
Climacteric; Menopause;
Arterial Hypertension;
Epidemiology 
Conclusion: Women in climacteric deserve special attention from health professionals, especially if this phase is associated with any pathology, such as hypertension. It is important for health professionals to develop strategies for early diagnosis, prevention and health promotion for women in the climacteric phase.

\section{Introduction}

Brazil is undergoing a significant aging process, and given these current demographic changes, the feminization of old age is increasing. This female overrepresentation is the result of the longer life expectancies of women.

According to the 2010 census of $190,755,199$ Brazilians, $51 \%$ of the population was female. Older people number $20,590,599$, representing $10.8 \%$ of the total population of which $55.5 \%(11,434,487)$ is female ${ }^{[1]}$.

The increase in life expectancy of the female population is reflected in a growing number of menopausal women, and data from the Department of the Unified Health System (DATASUS) show that of the 98 million Brazilian women, 30 million are between 35 and 65 years old, which is the age range in which menopause occurs, according to the Ministry of Health, Brazil[2].

Menopause is a stage of the female life cycle during which the transition from the reproductive to the non-reproductive period occurs. This process is physiological, characterized by ovarian failure, and marked by the end of menstruation. Some women experience this change in a healthy way, while others experience symptoms that vary in intensity and diversity, such as fatigue, anxiety, insomnia, hot flashes, and others that can trigger diseases linked to bone and lipid metabolism.
The International Menopause Society divides climacteric into three phases: premenopause, which usually begins after age 40, with reduced fertility and either irregular or regular menstrual cycles, compared to what occurred in their reproductive period; perimenopause, which begins two years before the last menstrual period and extends for a year after and is usually marked by irregular cycles and endocrine disorders; and postmenopause, which begins one year after the last menstrual period and is subdivided into early (five years after menopause) or late (more than five years after the last menstrual period) [3]

One of the prevalent diseases in menopause is high blood pressure (hypertension). Menopause has been identified as a contributing factor in the development of hypertension in women due to subsequent hormonal deficiency, which can cause alterations in vasoactivity (vasospasm), resulting in increased vascular tone and, hence, increased blood pressure (BP) and decreased tissue blood flow ${ }^{[4]}$.

Poor eating and lifestyle habits are primarily responsible for the increase in the number of women with hypertension because it is a condition linked to environmental, behavioral and dietary factors.

Considering the increase in life expectancy for women and various complaints that they have during menopause, when they experience high blood pressure, there is an overlap of events (symptoms of menopause and high BP). Therefore, monitoring 
and guidelines are required to maintain quality of life and prevent health problems.

This study is relevant, because there is a need for further research in this area, especially at the local level, considering women's workloads and overlapping events. Thus, the intention to conduct this research was anchored on the assumption that, in contemporary times, women perform a number of activities that can contribute to the onset of hypertension in adulthood as well as increased climacteric symptoms, especially if they do not have healthy lifestyles that include physical activity.

Thus, this research aims to determine both the prevalence of hypertension in women and the level of climacteric symptoms in hypertensive women in the city of Cajazeiras, Paraiba.

\section{Method}

This is a quantitative, cross-sectional study performed at 14 family health units (USF) in the urban areas of the city of Cajazeiras, PB from January 2013 to March 2014. This municipality is located in the hinterland $476 \mathrm{~km}$ from the capital, and according to the last census conducted by the Brazilian Institute of Geography and Statistics, ${ }^{[5]}$ it has a land area of $566 \mathrm{~km}^{2}$ and 58,443 inhabitants.

The sample of this research was calculated probabilistically based on a sample calculation of a finite population, adopting a significance level of $5 \%$, a sampling error of $5 \%$ and a $95 \%$ confidence interval based on a population of 9996 women aged 35 to 65 years ${ }^{[5]}$. The calculated sample to be investigated was 385 women. However, 543 interviews were conducted. The included participants were women aged 40-60 years. This range was used because before age 40, climacteric symptoms are virtually absent, and after age 60, women rarely have climacteric complaints due to physiological adaptation. The following exclusion criteria were applied: women whose climacteric complaints were absent, women who had undergone hysterectomy and women who used hormone replacement therapy (HRT) and/or hormonal contraceptives because they interfere with climacteric symptoms. After exclusion, the final sample included 396 women.

The data collection was performed through structured interviews, taking advantage of women's visits to the 14 USF locations for Pap smears, Hypertension and Diabetes (HIPERDIA) Program consultations and home visits, with community health workers.

The intensity of climacteric symptoms was assessed quantitatively by Blatt-Kupperman Menopausal Index (BKMI). Eleven symptoms are considered in this index: hot flashes, paresthesia, insomnia, nervousness, depression, dizziness, fatigue, arthralgia/ myalgia, headaches, palpitations and tingling.

To determine the BKMI, the various symptoms are scored according to their intensity, being cataloged as mild, moderate or severe. Vasomotor symptoms were scored according to the intensity of received values as 4, 8 and 12; paresthesia, insomnia and nervousness were scored as 2, 4 and 6; and depression, dizziness, weakness, arthralgia/ myalgia, headache, palpitations and tingling were scored as 1, 2 and 3. These values were summed, and the index categories were divided as follows: mild, up to 19 points; moderate, 20 to 35 points; and severe, greater than 35 points[6].

The data collection instruments were listed sequentially. The variables analyzed consisted of demographic data: age, education, per capita income, color, marital status and occupation; lifestyle factors: physical activity, meals/day, smoking and BMl; and the presence of hypertension, which was confirmed by registering with the HIPERDIA program and the use of hypotensive treatment.

Descriptive statistics, that is, the mean and standard deviation of the age, education and income per capita variables, were based on the 396 women interviewed. However, the prevalence of climacteric symptoms was described based on the 139 women with hypertension. To determine the prevalence and 
association of hypertension and correlated variables, we used odds ratios with $95 \%$ confidence intervals. This association was confirmed using a linear regression model. Excel and the SPSS Statistics software package version 22 (free to download) were used for the analysis and tabulation of the data.

This research is part of the project "Symptoms of menopause: severity and associated factors," which was approved by the Research Ethics Committee of the State University of Paraíba - UEPB as protocol number $0462.0 .133 .000-11$, on $14^{\text {th }}$ September, 2011.

The ethical aspects were considered in this study. This research followed the recommendation of Resolutions 196/96 and 466/2012 of the National Health Council, which governs research with human subjects. The subjects involved are guaranteed clarification of any desired aspect as well as the freedom to refuse to participate in the study, withdraw consent or discontinue participation at any time. Participation in the study was voluntary, and confidentiality of the information and anonymity were guaranteed. Women were included in the sample after they had read, understood and signed two copies of a Free and Clear Informed Consent (FCIC) form, one for the woman and one for the researcher responsible for the interview.

\section{Results}

\section{Sociodemographic Features of the Women Interviewed}

The women interviewed were on average 50 $( \pm 5.801)$ years of age, had $7( \pm 4.733)$ years of education and a per capita income $0.5( \pm 0.6958)$ times the minimum wage $(M W) ; 69.9 \%(n=277)$ had a fixed partner and $51.8 \%(n=205)$ were white (Table 1).

The prevalence of hypertension was $35.1 \%(n=$ $139)$ of which $63.3 \%(n=88)$ of the women complained of hypertension, $20.9 \%(n=29)$ reported hypertension associated with type I or II diabetes, and $15.8 \%(n=22)$ reported hypertension associated with other diseases, including cancer, osteoporosis or hormonal disorders of the thyroid (Table 1).

Table 1. Sociodemographic characteristics and prevalence of SAH in 396 climacteric women resident in the municipality of Cajazeiras, Paraiba, Brazil, 2013-2014.

\begin{tabular}{|c|c|c|}
\hline Characteristics & Total & Results \\
\hline Age $^{*}$ & 396 & $50( \pm 5.801)$ \\
\hline Schooling* & 396 & $7( \pm 4.733)$ \\
\hline Per capita income* & 396 & $0.5( \pm 0.6958)$ \\
\hline Marital status & 396 & $69.9 \%(n=277)$ \\
\hline Skin color (self-reported) & 396 & $51.8 \%(n=205)$ \\
\hline Presence of SAH & 396 & $35.1 \%(n=139)$ \\
\hline Only SAH & 139 & $63.3 \%(n=88)$ \\
\hline SAH and diabetes type I or II & 139 & $20.9 \%(n=29)$ \\
\hline SAH and other diseases & 139 & $15.8 \%(n=22)$ \\
\hline
\end{tabular}

*Average (standard deviation)

Source: Research data. 
Table 2. The relationship between SAH and sociodemographic variables $(n=396)$. Cajazeiras, Paraíba, Brazil, 2013-2014.

\begin{tabular}{|l|c|}
\hline Categories & $\begin{array}{c}\text { SAH }(\mathbf{n = 1 3 9 )} \\
\text { Prevalence ratio } \\
95 \% \mathrm{Cl}\end{array}$ \\
\hline Age $\mathbf{5 1}$ to $\mathbf{6 0}$ & $\begin{array}{c}2.164(1.417- \\
3.306)\end{array}$ \\
\hline $\mathbf{0}$ to $\mathbf{7}$ years of education & $1.434(0.947-$ \\
& $2.173)$ \\
\hline Activity at home & $1.686(1.103-$ \\
\hline Non-remunerated occupation & $2.576)$ \\
\hline
\end{tabular}

Source: Research data.

SAH versus Sociodemographic Variables, Lifestyle, Menopausal Status, and BKMI

When analyzing the participant data, as shown in Table 2, the presence of hypertension was significantly associated with age, exercise and professional activities in the home. There was no association between hypertension and schooling or unpaid occupation.

The data shown in Table $\mathbf{3}$ show the relationship between the presence of hypertension and variables related to lifestyle and menopausal stage. Hypertension was significantly associated with overweight/ obesity, postmenopause and a BKMI score indicating severe symptoms. No association was found between hypertension and smoking.

Table 4 shows the most prevalent symptoms in the study, other than hypertension: arthralgia (84.9\%), nervousness (84.2\%) and fatigue (81.3\%). However, there significant percentages of other symptoms were reported.

\section{Discussions}

The average age of the interviewed women (Table 1) was equivalent to a previous investigation of 260 women, which reported an average age of
Table 3. The relationship SAH with lifestyle-related variables and menopausal stage $(n=396)$. Cajazeiras-PB, Paraiba, Brazil, 2013-2014.

\begin{tabular}{|l|c|}
\hline Categories & $\begin{array}{c}\text { SAH }(\mathrm{n}=139) \\
\text { Prevalence ratio } \\
95 \% \mathrm{Cl}\end{array}$ \\
\hline Overweight/obesity & $2.748(1.738-4.343)$ \\
\hline Smoking & $0.885(0.529-1.482)$ \\
\hline Postmenopause & $2.180(1.432-3.321)$ \\
\hline High BKMI score & $3.143(1.608-6.146)$ \\
\hline
\end{tabular}

Source: Research data.

50 years old and living in a stable union. However, the average years of study in that survey exceeded eight years, and per capita income was near the minimum wage ${ }^{[7]}$. With regard to education, Leite

Table 4. Prevalence of menopausal symptoms in hypertensive women ( $n=139)$. Cajazeiras-PB, 20132014.

\begin{tabular}{|l|c|}
\hline Symptoms & $\%(\mathbf{n})$ \\
\hline Arthralgia & $84.9(118)$ \\
\hline Nervousness & $84.2(117)$ \\
\hline Tiredness & $81.3(113)$ \\
\hline Sadness/melancholy & $79.1(110)$ \\
\hline Hot flushes & $77.7(108)$ \\
\hline Paresthesia & $76.3(106)$ \\
\hline Sleep problems & $74.1(103)$ \\
\hline Vertigo & $71.9(100)$ \\
\hline Palpitation & $69.8(97)$ \\
\hline Headache & $69.1(96)$ \\
\hline Analgesia of members & $69.1(96)$ \\
\hline
\end{tabular}

Source: Research data. 
et al. ${ }^{[8]}$ found that the majority of menopausal women completed elementary school (55\%), which is less than eight years of study.

In this regard, research including hypertensive women in the climacteric period has found a higher prevalence of married women who have not completed primary education and a family income between 1 and 1.5 times the minimum wage. However, most were mixed with an age range of 60 to 65 years old $[9]$.

In general, the data in this study (Table 1) show socioeconomic and educational precariousness. Analyzing the sociodemographic profile of the menopausal women is an important tool to detect the relationship between hypertension and menopause because the number of hypertensive women increases with advancing age, which coincides with the climacteric period.

The low level of education observed in this study (Table 1) allows one to consider a direct relationship with low socioeconomic status. Several studies have examined the association between hypertension and economic situation, which in turn is associated with other risk factors for hypertension ${ }^{[10]}$.

The percentage of hypertensive women increased with age, revealing a direct relationship between hypertension and aging. This study takes place in Brazil, where hypertension is more prevalent in women, especially among those older than 65 [11].

With regard to education, no relationship was observed with hypertension (Table 2). However, education is paramount in the adoption of health promotion and disease prevention practices. Jesus and Neves ${ }^{[12]}$ claim that the level of education does not determine the appearance of a pathology; however, a person with a higher level of knowledge can more easily pursue disease prevention strategies and perform self-care, and education is central to better understanding of and adherence to a treatment.

It is not just exercise activities outside the home that reduce the hypertension rates among women. Professional qualifications are associated with more education and therefore with increased adoption of healthy lifestyles. Research has proven the importance of women entering the labor market in many ways, noting that paid work has proved to be a protective factor against anxiety and depression in menopausal women who have approximately five times lower risk of developing the pathologies studied $^{[13]}$

In turn, income may allow better or faster access to health services and adherence to private health plans, enabling early diagnosis of disease and the use of preventive measures ${ }^{[14]}$.

The findings draw attention to comorbidities associated with hypertension (Table 1). Women have a significant increase in cardiovascular risk between the ages of 50 and 64 . This change in cardiovascular risk profile coincides with climacteric changes and is characterized by the emergence or worsening of some risk factors: central obesity, hypertension and dyslipidemia[15]

Regarding the association of hypertension with other diseases, research conducted in 2012 $2^{[16]}$ showed that in both sexes, the prevalence of diabetes associated with hypertension increases with age, and the highest prevalence is observed in women.

Corroborating the results of this study (Table 1), research conducted in Brazil found that the prevalence of comorbid conditions was higher in the postmenopausal group, and of these co-morbidities, hypertension, diabetes mellitus, disease rheumatic, neoplasms and stroke were emphasized ${ }^{[17]}$.

Previous research was conducted and found similar results in a sample of 323 postmenopausal women; the majority (64.4\%) had confirmed previous clinical comorbidities: a history of cancer, hypertension, diabetes and acute myocardial infarction ${ }^{[18]}$.

Climacteric women are more likely to develop cardiovascular disease due to a gradual decrease of hormones. Coronary artery disease is two to three times more common after menopause, and this can be associated with the accumulation of visceral fat, which increases during menopause ${ }^{[19]}$. 
Several population studies have shown that obesity is a major risk factor for hypertension ${ }^{[20]}$ whose prevalence doubles in young adults (20-39 years old) and is at least 50\% higher in older adults (40-49 years old) who are overweight compared to normal weight subjects ${ }^{[21]}$.

In a study of 408 individuals of both sexes, hypertension prevailed among women, with obesity as one of the main risk factors, and those aged 50-59 years old were more likely to suffer from hypertension ${ }^{[22]}$.

Smoking is a risk factor for high blood pressure. However, in this study, it was not associated with the presence of hypertension (Table 2). One of the causes of early menopause is smoking due to the estrogen deficiency caused by tobacco use, resulting in not only anticipating the onset of the symptoms of menopause but also in conditions, such as osteoporosis and cardiovascular disease ${ }^{[8]}$.

Regarding the association between hypertension and menopause (Table 3), premenopausal women have lower blood pressure than men of the same age. However, as they grow older, women have higher rates of hypertension than men, suggesting that female hormones play an important role in hypertension. However, determining that role in the pathogenesis of hypertension is complex due to the effects of aging on the cardiovascular system and its relationship with other risk factors, such as body weight and cholesterol levels ${ }^{[23]}$.

According to the above author, endothelial dysfunction, and reduced vascular tone modulator vasodilators are associated with disease, including hypertension and atherosclerosis; this may be the mechanism by which estrogen deficiency can cause hypertension.

The significant association of hypertension with the menopausal/postmenopausal period found in this study (Table 3) is supported by Santos, Silva and Monteiro [24], who found a high prevalence of hypertension in the women interviewed; these respondents were 50 years old, on average, and in
$40 \%$ of them, hypertension was associated with menopause.

In justifying the association between hypertension and severe climacteric symptoms (Table 3), we would emphasize ovarian failure and the decline of hormones during the menopausal and postmenopausal stages and its relationship with cardiovascular disease.

Research analyzing the influence of sex hormones in modulating endothelial function has shown that estrogen plays an important role in the regulation of endothelium. In hypertensive women, entering menopause has been associated with the development or exacerbation of endothelial dysfunction. The renin-angiotensin system (RAS) is also influenced by female sex hormones. This system is important in the regulation of vascular tone and growth ${ }^{[4]}$.

Thus, that hypertension was more prevalent in women with pronounced climacteric symptoms may be related to this phenomenon because the negative influence of this hormone decline is linked to vasomotor, psychological and urogenital symptoms, increasing tone and causing high blood pressure.

Climacteric symptoms are self-reported complaints; most are subjective in nature and therefore difficult to measure. They can often be overestimated or exacerbated by the participant at the time of collection, which is one of the limitations of the research. The women were also evaluated at a single time point.

Corroborating the results in Table 4, in research aimed at identifying information on menopause, its signs and symptoms and self-care measurements, it was identified that all respondents had more than one symptom/sign among those listed in the interview guide, with the most prevalent symptom being arthralgia/myalgia (74\%) ${ }^{[25] .}$

Research that aimed to identify factors that are predictors of climacteric symptoms found that the most prevalent symptoms were irritability (87.1\%), arthralgia/myalgia (77.5\%) and melancholy/sadness $(73.2 \%)^{[26]}$. 
In the present study (Table 4), arthralgia, nervousness and fatigue were the most frequent climacteric symptoms, whereas hot flushes, identified in several national and international studies as major symptoms, were not among the symptoms most cited by women.

Overall, these findings constitute important implications for health services, stressing that these women require adequate and special attention. The frequency and intensity of hot flashes and other prevalent symptoms in menopause that compromise women's quality of life require special attention [27]

Menopause is experienced in different ways by different women; there are variations in symptoms and in physical, demographic, socioeconomic and cultural aspects, which result in peculiar perceptions and experiences of this phase among women worldwide.

In Brazil, considering the continental dimensions and regional characteristics, it is not expected that the climacteric experience is similar among women from different regions and even those of a common region. These differences become even more emphatic when considering that a significant part of the population lives in suburban and rural areas, where low education, low family income and high morbidity and mortality resulting from diseases linked to poor socioeconomic conditions are prevalent ${ }^{[28]}$.

It is essential, however, that menopausal women have access to health information so that they understand how changes occur during this period and so that they are able to understand the signs and symptoms that are present or may be present because women often attribute menopause symptoms to medical comorbidities or previous emotional difficulties, distorting their perception of this phase of their lives ${ }^{[25]}$.

\section{Conclusions}

The changes caused by menopause have an impact on various aspects of life, including interpersonal relationships, roles as professional-womanmother-wife, and discomfort caused by body changes, body image and relationship with aging. The overlap of these factors and hypertension leads to a sharp increase of climacteric symptoms compared to women who do not have hypertension.

Although there are limitations of this research because it was conducted at a single moment, without intervention, without following the study population, failing to have specific laboratory tests conducted, and self-reporting symptoms, the results raise hypotheses about hypertension that deserve further investigation. Due to the complexity of the issue in question, much remains to be investigated.

Concerning the health of the climacteric women, the encouragement of research is essential to facilitate the understanding of what happens during this phase, contributing to a better understanding and improving the quality of life of these women. Finally, it is important for health professionals to develop strategies for early diagnosis, prevention of hypertension and health promotion for women in the climacteric phase.

\section{References}

1. IBGE. Brazilian Institute of Geography and Statistics. 2010 demographic sense. Rio de Janeiro, Brazil, 2011. ibge.gov.br/ home/presidencia/noticias/imprensa/ppts/0000000402.pdf

2. Ministry of health (BR). Secretariat for health care.Instruction manual attention to Woman in Climacteric/Menopause. Brasília: Ministry of health; 2008. Available from: <bvsms.saude.gov. $\mathrm{br} / . . . /$ manual_atencao_mulher_climaterio.pdf>

3. Beltramini ACS, Diez CAP, Camargo IO, Preto VA. The nurse actions regarding the importance of women healthcare in climacteric. Revista Mineira de Enfermagem. 2010 apr june; 14(2): 166-74. Available from: <http://reme.org.br/ 
artigo/detalhes/102> DOI: http://www.dx.doi.org/S141527622010000200004

4. Barbosa E, Guimarães JI, Saraiva R. Arterial hypertension systemic and the woman. Revista da Sociedade de Cardiologia do Rio Grande do Sul. 2008 sept/oct/nov./dec; year 16(15): 1-5.

5. IBGE. Brazilian Institute of Geography and Statistics. IBGE cidades@. Cajazeiras - PB: basic data. Available from: $\quad<$ http://www.ibge.gov.br/cidadesat/painel/painel. php?codmun=250370>

6. Wender COM, Freitas F, De Castro JAS, Vanin C. Climacteric. In: Freitas F, Menke $\mathrm{CH}$, Rivoire WA, Passos EP. Routines in gynecology. Porto Alegre: Artmed; 2011. p. 542-60.

7. Alves ERP, Calazans JCC, Ferreira AYM, Leite GO, Barboza KKS, Dias MD. Association between record gynecological-obstetrics and climacteric symptoms. Rev Enferm UFSM, v. 3, n. 3, p. 490499, set./dez. 2013. Avalable from: <http://cascavel.ufsm.br/ revistas/ojs-2.2.2/index.php/reufsm/article/view/10567/pdf>. Doi: 10.5902/2179769210567

8. Leite ES, Oliveira FB, Martins ÁKL, Ramalho KKA, Torquato $J A$. Perspectives on women climacteric: concepts and impacts on health basic care. R. pesq.: cuid. fundam. Online, 2012 oct dec; 4(4): 2942-52. Available from: <http://www.seer.unirio.br/ index.php/cuidadofundamental/article/view/1850/pdf_636\#>. Doi 10.9789/2175-5361

9. Pasklan ANP, Sardinha AH Lima, Nascimento JS, Gomes B. The profile of hypertensive women in climacterium attended at the program HIPERDIA. J. res.: fundam. care. Online, 2014 jan mar; 6(1): 249-60. Available from: <http://www.seer.unirio.br/index. php/cuidadofundamental/article/view/2689/pdf_1041> Doi: 10.9789/2175-5361.2014v6n1p249

10. Araujo JC, Guimarães AC. Control of arterial hypertension in a family care unit. Rev Saúde Pública, São Paulo. 2007 june; 41(3): 368-74. Available from: <http://www. scielo.br/scielo.php?script=sci_arttext\&pid=S003489102007000300007\&lng=en>. http://dx.doi.org/10.1590/ S0034-89102007000300007.

11. Moreira JPL, Moraes JR, Luiz RR. Prevalence of self-reported systemic arterial hypertension in urban and rural environments in Brazil: a population-based study. Cad. Saúde Pública., Rio de Janeiro, 2013 jan; 29(1): 62-72. Available from: <http://www. scielo.br/scielo.php?script=sci_arttext\&pid=S0102-311X201300 0100008\&lng=en\&nrm=iso>. http://dx.doi.org/10.1590/S0102$311 \times 2013000100008$

12. Jesus ES, Neves RS. Nursing diagnoses in spinal cord injured patients. Porto Alegre: Brazilian Association of nursing, 2006.

13. Polisseni ÁF, Araújo DAC, Polisseni $F$, Mourão Junior CA, Polisseni J, Fernandes ES et al. Depression and anxiety in menopausal women: associated factors. Rev. Bras. Ginecol. Obstet. [online]. 2009 mar; 31(1): 28-34. Available from: <http:// www.scielo.br/scielo.php?script=sci_arttext\&pid=S010072032009000300003\&lng=en>. http://dx.doi.org/10.1590/ S0100-72032009000300003.
14. Colet CF, Mayorga P, Amador TA. The use of medications by seniors entered in groups of coexistence in the city of Porto Alegre/RS/Brazil. Lat. Am. J. Pharm. 2008; 27 (3): 460-7. Available from: <http://www.latamjpharm.org/trabajos/27/3/ LAJOP_27_3_3_4_09HK9Z6E90.pdf >

15. Figueiredo Neto JA, Figuerêdo ED, Barbosa JB, Barbosa FF, Costa GRC, Nina VJS et al. Metabolic syndrome and menopause: cross-sectional study in gynecology clinic. Arq. Bras. Cardiol. [Online], 2010 jul; 95(3): 339-45. Available from: <http:// www.scielo.br/scielo.php?script=sci_arttext \&pid=\$0066782X2010001300010\&lng=en>. http://dx.doi.org/10.1590/ S0066-782X2010005000094.

16. Freitas LRS, Garcia LP. Evolution of prevalence of diabetes and associated hypertension in Brazil: analysis of National Household Sample Survey, 1998, 2003 and 2008. Epidemiol. Serv. Saúde, Brasília, 2012 jan mar; 21(1): 7-19. Available from: <http:// scielo.iec.pa.gov.br/scielo.php?script=sci_arttext\&pid=S167949742012000100002\&lng=pt>. http://dx.doi.org/10.5123/ S1679-49742012000100002.

17. De Lorenzi DRS, Catan LB, Cusin T, Felini R, Bassani F, Arpini $A C$. Characterization of the quality of life by menopausal status among women in the South region of Brazil. Rev. Bras. Saúde Mater. Infant. [online]. Recife 2009; 9(4): 459-66. Disponível: $<$ http://www.scielo.br/pdf/rbsmi/v9n4/a11v9n4.pdf> Acessado em: 10/02/2015. Available from <http://www.scielo.br/scielo. php? script=sci_arttext $\&$ pid $=$ S1519-38292009000400011\&In $\mathrm{g}=$ en\&nrm=iso>. $\quad$ http://dx.doi.org/10.1590/S1519. 38292009000400011

18. De Lorenzi DRS, Baracat EC, Saciloto B, Padilha Jr. I. Associated factors the quality of life after menopause. Rev. Assoc. Med. Bras. [online]. 2006 oct; 52(5): 312-17. Available from: <http:// www.scielo.br/scielo.php?script $=$ sci_arttext\&pid=S010442302006000500017\&lng=en>. http://dx.doi.org/10.1590/ S0104-42302006000500017.

19. Takamune DM, Maruichi MD, Pai CYW, Silva CSHA, Amadei G, Lima SMRR. Knowledge of risk factors for cardiovascular disease in the climacteric period: pilot study. Arq Med Hosp Fac Cienc Med Santa Casa São Paulo. 2011;56(3):117-21. Disponível: <http://www.fcmscsp.edu.br/files/AO25.pdf>

20. Santos BMP, Farias MCAD, Daltro $C$, Abreu LC, Valenti VE, Bezerra IMP et al. Metabolic syndrome in elderly from a northeastern brazilian city. International Archives of Medicine, v. 8, p. 1-8, 2015. Available from: <http://imed.pub/ojs/index. php/iam/article/view/1009/683> doi: 10.3823/1619

21. Carneiro G, Faria $A N$., Ribeiro Filho FF, Guimarães $A$, Lerário $D$, Ferreira SRG et al. Influence of body fat distribution on the prevalence or arterial hypertension and other cardiovascular risk factores in obese patients. Rev. Assoc. Med. Bras. [serial on the Internet]. 2003 sep; 49( 3 ): 306-11. Available from: <http:// www.scielo.br/scielo.php?script=sci_arttext $\&$ pid $=\$ 0104-$ 42302003000300036\&lng=en>. http://dx.doi.org/10.1590/ S0104-42302003000300036 
22. Radovanovic CAT, Santos LA, Carvalho MDB, Marcon SS. Arterial hypertension and other risk factors associated with cardiovascular diseases among adults. Rev. LatinoAm. Enfermagem, Ribeirão Preto, 2014 aug; 22(4): 547-53. Available from <http://www.scielo.br/scielo.php?script=sci_ arttext\&pid=S0104-11692014000400547\&lng=en\&nrm=iso > . http://dx.doi.org/10.1590/0104-1169.3345.2450

23. Barton M, Meyer MR. Postmenopausal hypertension: mechanisms and therapy. hypertension. American Heart Association, 2009; 54, p. 11-8. Disponível em: <http://hyper. ahajournals.org/content/54/1/11.full.pdf > DOI: 10.1161/ HYPERTENSIONAHA.108.120022

24. Santos ZMSA, Silva RM, Monteiro DA. Hypertensive woman and the relation with menopause. Rev. RENE. Fortaleza, 2006 jan abr; 7(1): 68-74. Available from:<http://www.revistarene.ufc.br/ revista/index.php/revista/article/view/770/pdf>

25. Valença CN, Germano RM. Women's conceptions about menopause and climateric. Rev. Rene, Fortaleza, 2010 jan./mar.; 11(1): 161-71. Disponível em: <http://www.revistarene.ufc.br/ revista/index.php/revista/article/view/366/pdf >

26. De Lorenzi DRS, Danelon C, Saciloto B, Padilha Jr. I. Predicting factors of climacteric symptoms. Rev. Bras. Ginecol. Obstet., 2005 jan; 27(1): 7-11. Available from: <http:// www.scielo.br/scielo.php?script=sci_arttext\&pid=S010072032005000100004\&lng=en>. http://dx.doi.org/10.1590/ S0100-72032005000100004.

27. Sclowitz IKT, Santos IS, Silveira MF. Prevalence and factors associated with hot flashes in climacteric and post-climacteric women. Cad. Saúde Pública, Rio de Janeiro, 2005 mar./ apr.; 21(2): 469-81. Available from: <http://www.scielo.br/ scielo.php?script=sci_arttext $\&$ pid $=$ S0102-311X200500020 0013\&lng=en\&nrm=iso>. $\quad$ http://dx.doi.org/10.1590/S0102$311 \times 2005000200013$

28. Silveira IL, Petronilo PA, Souza MO, Costa e Silva TDN, Duarte JMBP, Maranhão TMO et al. Prevalence of climacteric symptoms in women living in rural and urban areas of Rio Grande do Norte, Brazil. Rev. Bras. Ginecol. Obstet., Rio de Janeiro, 2007 ago; 29(8): 415-52. Available from: <http://www.scielo.br/scielo. php?script=sci_arttext $\&$ pid $=$ S0100-72032007000800006\&ln $\mathrm{g}=\mathrm{en} \& \mathrm{nrm}=\mathrm{iso}>$. http://dx.doi.org/10.1590/S0100-

\section{Comment on this article:}

\section{(f) $[$ in $8+\boldsymbol{S}$ P}

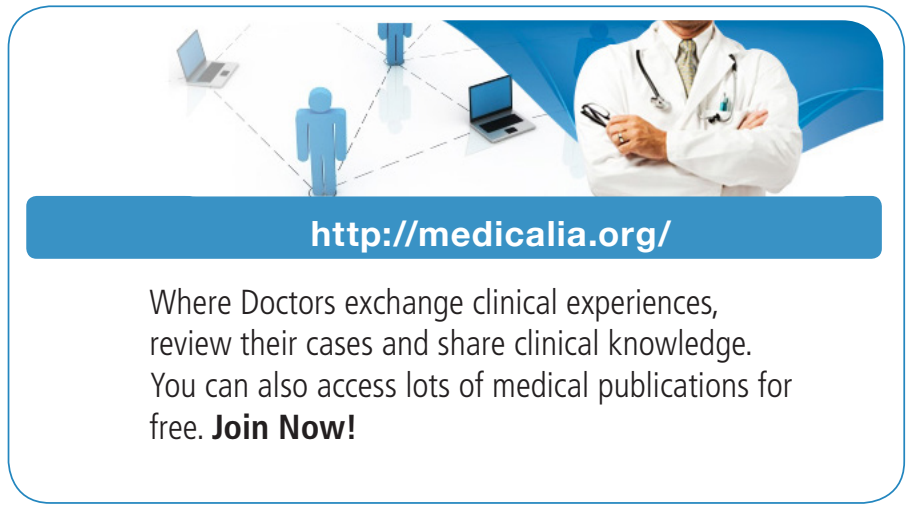

\section{Publish with iMedPub}

\section{http://www.imed.pub}

International Archives of Medicine is an open access journal publishing articles encompassing all aspects of medical science and clinical practice. IAM is considered a megajournal with independent sections on all areas of medicine. IAM is a really international journal with authors and board members from all around the world. The journal is widely indexed and classified Q1 in category Medicine. 